\title{
Accuracy of Palate Shape as sex Indicator in Human Skull with Maxillary Teeth Loss
}

\author{
Exactitud de la Forma del Paladar como Indicador de Sexo \\ en Cráneos Humanos con Pérdida de Dientes Maxilares \\ *,**Iván Claudio Suazo Galdames; *Daniela Alejandra Zavando Matamala \& ** Ricardo Luiz Smith
}

SUAZO, G. I. C.; ZAVANDO, M. D. A. \& SMITH, R. L. Accuracy of palate shape as sex indicator in human skull with maxillary teeth loss. Int. J. Morphol., 26(4):989-993, 2008.

SUMMARY: In forensic medicine, diagnosis of sex is the first step in the identification of human skulls. A first approximation is carried out via the qualitative analysis of a series of morphological indicators of sexual dimorphism. Classical studies (Krogman \& Iscan, 1986) described 14 indicators for the diagnosis of sex with an accuracy of $90 \%$, and one of these indicators is the shape of the palate. This study analyzed the effect of the loss of teeth on the accuracy of the diagnosis of sex in Brazilians adult skulls, using the shape of the palate as an indicator. We used 98 skulls of adult Brazilians, comprising 35 females and 63 males with an average age of 39.3 years (SD 7.8). The skulls were classified into two groups, namely the fully edentulous maxilla and the partial edentulous maxilla. An inclusion criterion in the partial edentulous maxilla group was the presence of canine or their alveolus. The accuracy for the diagnosis of sex in the total sample was $75.5 \%$ (with a sensitivity of $88.8 \%$ for male skulls and $51.5 \%$ for female skulls), while it was slightly higher (76.9\%) in the fully edentulous maxilla group with a sensitivity from $84 \%$ to $70 \%$ for both male and female skulls. However, the partial edentulous maxilla group presented lower values of accuracy of $74.5 \%$, and a sensitivity of $90 \%$ for male skulls and $26 \%$ for female skulls. Thus, this work suggests that the accuracy of diagnosis of sex using the shape of the palate as an indicator of sexual dimorphism is not significantly affected by full edentulism; however, the presence of teeth favors the underestimation of the female skulls

KEY WORD: Sexual Dimorphism; Sex determination; Palate; Tooth loss.

\section{INTRODUCTION}

The diagnosis of sex is the key to the anthropological and forensic analysis carried out on bones. Various methods have been described based on the cranial observations, overall dimensions, and angles formed between the craniometric points (Baughan \& Demirjian, 1978; Lestrel et al., 2005; Ursi et al., 1993; Olivier \& Tissier, 1977; Bibby, 1979), in the temporal bone (Kalmey \& Rathbun, 1996; de Paiva \& Segre, 2003; Kemkes \& Gobel, 2006), in the frontal bone (Celbis et al., 2001), in the occipital bone (Wescott \& Moore-Jansen, 2001 ), in the mandible (Panella et al., 1988; Buschang et al., 1986; Rosas et al., 2002; Steyn \& Iscan, 1998; Franklin et al., 2007; Schmittbuhl et al., 2001; Loth \& Henneberg, 1998; Loth \& Henneberg, 1996; Balci et al., 2005; Haun, 2000; Lam et al., 1996), in the orbit (Graw et al., 1999; Schleyer et al., 1971), and in the dental pieces (Introna et al., 1993; Kondo et al., 2005; Abdelmalek \& Michael, 1984).

Although various statistical models have been developed to conduct a quantitative analysis of the morphological indicators of dimorphism, determining the sex by visual inspection is still widely used in physical anthropology. However, the skeletal characteristics vary in different populations, and hence, specific analyses are required (Steyn \& Iscan). This requirement was evident after an indigenous South African skulls study, in which determining the presence of sexual dimorphism using the classic indicators described by Krogman was not possible, as distinctive features between male and female skulls were observed, some of which were not described for the Caucasian population (Franklin et al., 2005). On the other hand, some researchers have described the influence of size and intra-sexual variations in certain populations (Kimmerle et al., 2008), by determining the errors in the diagnosis of sex by traditional methods, based on the classical parameters described by Krogman \& Iscan (1986).

In a review of morphological indicators of sexual dimorphism, 17 most important morphological indicators used by researchers were analyzed, and their values as the

\footnotetext{
* Departamento de Anatomía Normal, Universidad de Talca, Chile.

** Departamento de Morfología y Genética. Universidade Federal de São Paulo, Brasil.
} 
determinants of sex in the modern skulls were established individually as well as collectively. The traits were evaluated and ranked using a collection of skulls of known sex, by setting the indicators in the determination of sex with a high degree of accuracy $(>80 \%)$, and with a low intraobserver error $(<10 \%)$. From this study, it was concluded that the best indicators of the morphological sexual dimorphism were the pyriform aperture, zygomatic process, zygomatic bone, and supraorbitary eminence. In another analysis, the shape of the palate ranked 13 and even presented a high reproducibility of results, as the accuracy decreased significantly with the advancing age (Rogers, 2005).

The palate shape can be determined in the first years of life by the fusion of the palatine process with the premaxilla region, and in the course of life it is subjected to multiple forces that shape their growth and determine its adult form. The way an adult is diagnosed by visual inspection is determined by how the palate presents the dental arch, or in the absence of teeth or tooth remnant of the alveolar process.

One of the main determinants of the shape of the palate is the pericanine region, which in the presence of the piece tends to preserve the curve of the arch in the area earlier, and its loss is caused by the reabsorption of alveolar bone in elevation and especially the vestibular bone plate. Against this background, this study aims to analyze the effect of the loss of teeth on the accuracy and sensitivity of the visual examination of the shape of palate, that as a classic indicator of dimorphism for the sex diagnosis

\section{MATERIAL AND METHOD}

By non-probability convenience sampling, 98 Brazilians adult skulls, comprising 35 female and 63 male skulls with an average age of 39.3 years (SD 7.8), belonging to the collection of skulls of the Universidade Federal de Sao Paulo (UNIFESP) were selected. The skulls that showed some evidence of trauma or anatomical alterations were excluded from this study. Also, approval for this study was obtained from the Ethics Committee in Research of UNIFESP.
During the analysis of this parameter, the examiner, experienced in diagnosing the sex of the skeletons, ignored the records of sex and age of the skulls throughout the study and was blinded to the distribution of the sample during the observation process. The examiner investigated the skull with both the hands and then rotated them to estimate the basal norm. The observation was made in two successive groups of 49 skulls at a time. Through visual inspection of the palate, the skulls were classified based on sex according to the following description:

Male skull: It is usually more in length and breadth than the female skull. It tends to take the closed U-shape (Fig. 1)..

Female skull: It is more narrow and shorter than the male skull, and this form tends to take a parabolic shape (Fig. 2).

We used the record of data collection created for the diagnosis of sex by visual examination of the human skulls, which was then subjected to analysis.

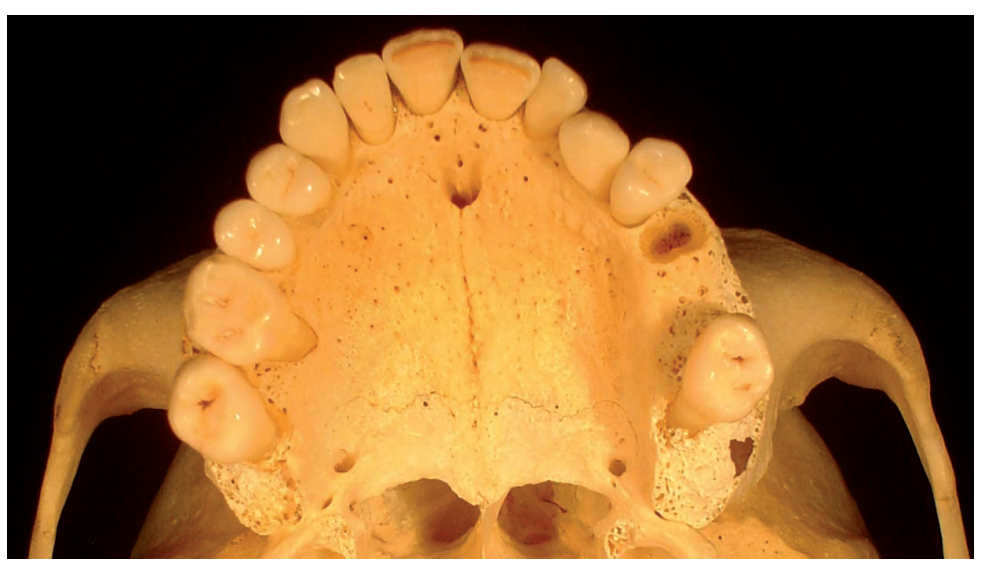

Fig. 1. Photograph of the palate of a 49 -year-old white man; the skull belongs to the UNIFESP collection.

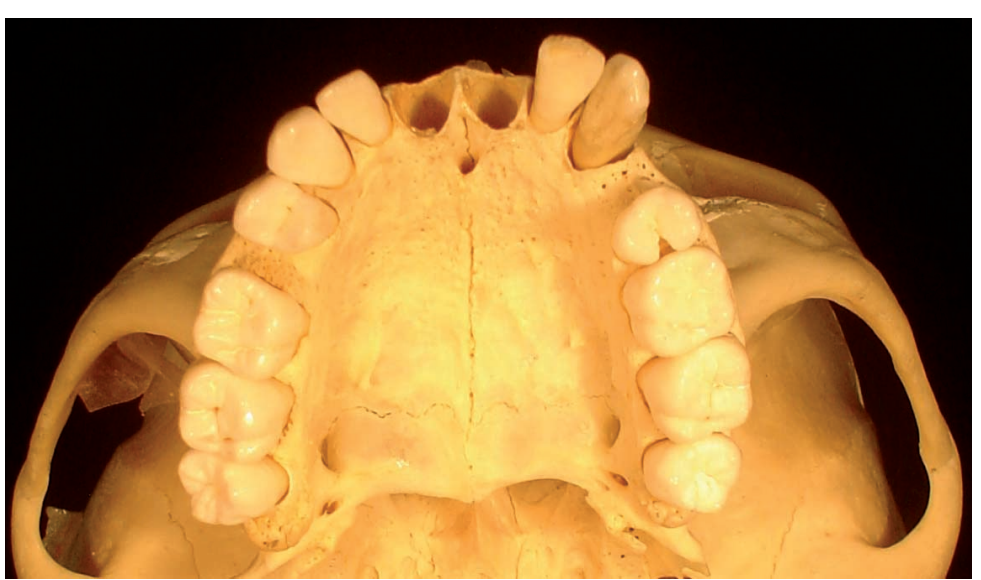

Fig. 2. Photograph of the palate of a 25 -year old white woman; the skull belongs to the UNIFESP collection. 
Subsequently, to determine the effect of the loss of teeth on the accuracy and sensitivity of the shape of the palate as an indicator of morphological dimorphism, the skulls were classified into two groups:

Fully edentulous maxilla group: It consisted of 39 skulls of individuals between 28 and 60 years of age (average 43.56 years, $\mathrm{SD}=8.281$ ), 19 of which were male and 20 female skulls.

Partial edentulous maxilla group: The criterion for inclusion in this group was the presence of both maxillary canine and alveolus with a slight reabsorption. This group was composed of 59 skulls of individuals between 25 and 49 years of age (average 36.49 years, $S D=6.05$ ), among which 44 belonged to male and 15 to female.

The data were analyzed using a contingency table of $2 ¥ 2$ for the indicator palate-shape, and the accuracy and sensitivity for male and female skulls were determined by the calculations made with the statistical program SPSS 15.0. Finally, using the remediation method for a random subsample of 30 skulls, the intra-observer error was calculated, 15 days after the first observation.

Table I. Contingency table of diagnosis of sex based on the study of palate shape of 98 skulls.

\begin{tabular}{llccc}
\hline & & \multicolumn{2}{c}{ Sex } & \\
\cline { 3 - 4 } & & Male & Female & Total \\
\hline Palate & Male & 56 & 17 & 73 \\
shape & Female & 7 & 18 & 25 \\
Total & & 63 & 35 & 98 \\
\hline
\end{tabular}

Table II. Contingency table of diagnosis of sex based on the palate shape of 39 skulls of the fully edentulous maxilla group

\begin{tabular}{llccc}
\hline & & \multicolumn{2}{c}{ Record } & \\
\cline { 3 - 4 } & & Male & Female & Total \\
\hline Palate & Male & 16 & 6 & 22 \\
shape & Female & 3 & 14 & 17 \\
Total & & 19 & 20 & 39 \\
\hline
\end{tabular}

Table III. Contingency table of diagnosis of sex based on the shape of the palate of 59 skulls of the partial edentulous maxilla group

\begin{tabular}{llccc}
\hline & & \multicolumn{2}{c}{ Record } & \\
\cline { 3 - 4 } & & Male & Female & Total \\
\hline Palate & Male & 40 & 11 & 51 \\
shape & Female & 4 & 4 & 8 \\
Total & & 44 & 15 & 59 \\
\hline
\end{tabular}

\section{RESULTS}

The accuracy of our test for diagnosis of the sex was $75.5 \%$ in the total sample (with a sensitivity of $88.8 \%$ for male skulls and $51.5 \%$ for female skulls). Table I shows the contingency table with the values analyzed together, without division of the groups.

The accuracy of fully edentulous maxilla group was about $76.9 \%$, with a sensitivity of $84-70 \%$ for both the male and female skulls. Table II shows the contingency table for the diagnosis of sex in the fully edentulous maxilla group.

The partial edentulous maxilla group exhibited lower values of accuracy of $74.5 \%$ and a sensitivity of $90 \%$ for male skulls and $26 \%$ for female skulls, and the data for this group are listed in Table III.

\section{DISCUSSION}

The use of palate shape as a part of the protocol for the diagnosis of sex in human skulls had been recommended by many researchers (Bass, 1971; Krogman \& Iscan; White \& Folkens, 2000).

However, the palate, during its development and life, is subjected to various forces that change their shape, such as chewing forces, forces of the tongue muscle, and perioral muscles (Moorres \& Reed, 1965; Raberin et al., 1993; Bishara et al., 1997). Lastly, the loss of teeth determines the reabsorption of the alveolar process, which creates distortions in the shape of the arch and the appearance of depth in the palate. These features are relevant, because the loss of teeth may affect the study of morphological dimorphism using the palate shape as a diagnostic indicator.

This study demonstrated that the accuracy of the diagnosis of sex was not significantly affected by the total edentulism, a situation different from what is expected, since the loss of canines amending the curvature of the arc in the anterior and reabsorption of the alveolar process gives a less thorough and robust shape on the palate. However, this study also revealed the low sensitivity in the diagnosis of the female toothless partial skulls and high sensitivity for male skulls, an observation different from those reported by Rogers. Furthermore, analysis of the results revealed that the presence of teeth favors the underestimation of female skulls, when the shape of the palate was used as an indicator in the investigation of sexual dimorphism. 
SUAZO, G. I. C.; ZAVANDO, M. D. A. \& SMITH, R. L. Exactitud de la forma del paladar como indicador de sexo en cráneos humanos con pérdida de dientes maxilares. Int. J. Morphol., 26(4):989-993, 2008.

RESUMEN: En medicina forense el diagnostico del sexo es el primer paso para la identificación de cráneos humanos completos o incompletos. Para ello una primera aproximación se realiza mediante el análisis cualitativo de una serie de indicadores morfológicos de dimorfismo sexual. Estudios clásicos (Krogman \& Iscan, 1986) describieron 14 indicadores que permitirían el diagnóstico del sexo con una exactitud del $90 \%$. Uno de estos indicadores es la forma del paladar, en este estudio se analizó el efecto de la pérdida de piezas dentales sobre la exactitud en el diagnóstico del sexo, en cráneos brasileros adultos, utilizando como parámetro de observación la forma del paladar. Se utilizaron 98 cráneos de individuos adultos brasileros con una edad media de 39.3 años (SD 7,8), 35 mujeres y 63 hombres. Los cráneos fueron clasificados en dos grupos, uno desdentado completo maxilar y otro desdentado parcial, un criterio de inclusión en el grupo de desdentados parciales fue la presencia de los caninos maxilares o de sus alvéolos. La exactitud para el diagnóstico del sexo en la muestra total fue del 75,5\% (Con una sensibilidad de 88,8\% para hombres y de 51,5\% para mujeres), la exactitud fue levemente mayor en el grupo de desdentados con un $76,9 \%$, con una sensibilidad de $84 \%$ para hombres y $70 \%$ para mujeres; mientras que el grupo de cráneos desdentados parciales presentó valores inferiores de exactitud, con un 74,5\%, y una sensibilidad del $90 \%$ para hombres y del $26 \%$ para mujeres. Este trabajo permite concluir que el edentulismo total no afecta considerablemente la exactitud del diagnóstico del sexo, pero la presencia de piezas dentarias favorece la subestimación de las mujeres al observar éste parámetro.

PALABRAS CLAVE: Dimorfismo sexual; Determinación del sexo; paladar; Pérdida dentaria.

\section{REFERENCES}

Abdelmalek, R. G. \& Michael, C. G. Sexual dimorphism in the mesiodistal width of the permanent maxillary anterior teeth in relation to their artificial replacements. Egypt. Dent. J., 30:107-18, 1984.

Balci, Y.; Yavuz, M. F. \& Cagdir, S. Predictive accuracy of sexing the mandible by ramus flexure. Homo, 55:229$37,2005$.

Bass, W. M. Human osteology: a laboratory and field manual of the human skeleton. Columbia, Missouri Archaeological Society, 1971.

Baughan, B. \& Demirjian, A. Sexual dimorphism in the growth of the cranium. Am. J. Phys. Anthropol., 49:38390, 1978 .

Bibby, R. E. A cephalometric study of sexual dimorphism. Am. J. Orthod., 76:256-9, 1979.

Bishara, S. E.; Jakobsen, J. R.; Treder, J. \& Nowak, A. Arch width changes from 6 weeks to 45 years of age. Am. J. Orthod. Dentofac. Orthop., 111(4):401-9, 1997.

Buschang, P. H.; Tanguay, R.; Demirjian, A.; La Palme, L. \& Goldstein, H. Sexual dimorphism in mandibular growth of French-Canadian children 6 to 10 years of age. Am. J. Phys. Anthropol., 71:33-7, 1986.

Celbis, O.; Iscan, M. Y.; Soysal, Z. \& Cagdir, S. Sexual diagnosis of the glabellar region. Leg. Med. (Tokyo), 3:16270, 2001. de Paiva, L. A. \& Segre, M. Sexing the human skull through the mastoid process. Rev. Hosp. Clin. Fac. Med. Sao Paulo, 58:15-20, 2003.

Franklin, D.; Freedman, L. \& Milne, N. Sexual dimorphism and discriminant function sexing in indigenous South African crania. Homo, 55:213-28, 2005.

Franklin, D.; Oxnard, C. E.; O'Higgins, P. \& Dadour, I. Sexual dimorphism in the subadult mandible: quantification using geometric morphometrics. J. Forensic Sci., 52:6-10, 2007.

Graw, M.; Czarnetzki, A. \& Haffner, H. T. The form of the supraorbital margin as a criterion in identification of sex from the skull: investigations based on modern human skulls. Am. J. Phys. Anthropol., 108:91-6, 1999.

Haun, S. J. Brief communication: a study of the predictive accuracy of mandibular ramus flexure as a singular morphologic indicator of sex in an archaeological sample. Am. J. Phys. Anthropol., 111:429-32, 2000.

Introna, F. Jr.; Cantatore, F.; Dragone, M. \& Colonna, M. Sexual dimorphism of deciduous teeth in medico-legal identification. Boll. Soc. Ital. Biol. Sper., 69:223-30, 1993.

Kalmey, J. K. \& Rathbun, T. A. Sex determination by discriminant function analysis of the petrous portion of the temporal bone. J. Forensic Sci., 41:865-7, 1996. 
Kemkes, A. \& Gobel, T. Metric assessment of the "mastoid triangle" for sex determination: a validation study. $J$. Forensic Sci., 51:985-9, 2006.

Kimmerle, E. H.; Ross, A. \& Slice, D. Sexual dimorphism in america: geometric morphometric analysis of the craniofacial region. J. Forensic Sci., 53:54-7, 2008.

Kondo, S.; Townsend, G. C. \& Yamada, H. Sexual dimorphism of cusp dimensions in human maxillary molars. Am. J. Phys. Anthropol., 128:870-7, 2005.

Krogman, W. M. \& Iscan, M. Y. The Human Skeleton. In Forensic Medicine. Springfield, lllinois, Charles C. Thomas Pub., 1986.

Lam, Y. M.; Pearson, O. M.; Smith, C. M. Chin morphology and sexual dimorphism in the fossil hominid mandible sample from Klasies River Mouth. Am. J. Phys. Anthropol., 100:545-57, 1996.

Lestrel, P. E.; Cesar, R. M. Jr.; Takahashi, O. \& Kanazawa, E. Sexual dimorphism in the Japanese cranial base: a Fourier-wavelet representation. Am. J. Phys. Anthropol., 128:608-22, 2005.

Loth, S. R. \& Henneberg, M. Mandibular ramus flexure: a new morphologic indicator of sexual dimorphism in the human skeleton. Am. J. Phys. Anthropol., 99:473-85, 1996.

Loth, S. R. \& Henneberg, M. Mandibular ramus flexure is a good indicator of sexual dimorphism. Am. J. Phys. Anthropol., 105:91-2, 1998.

Moorres, C. F. A. \& Reed, R. B. Changes in dental arch dimensions expressed on the basis of tooth eruption as a measure of biologic age. J. Dent. Res., 44:129-41, 1965.

Olivier, G. \& Tissier, H. Sexual dimorphism of correlations in crainometry. Bull. Assoc. Anat. (Nancy), 61:259-67, 1997.

Panella, J.; de Freitas, A.; Varoli, O. J. \& da Silva, M. Sexual dimorphism in linear analysis of the mandible using elipsopantomographic pantomograms. Rev. Odontol. Univ. São Paulo, 2:92-6, 1988.

Raberin, M.; Laumon, B.; Martin, J. L. \& Brunner, F. Dimensions and form of dental arches in subjects with normal occlusions. Am. J. Orthod. Dentofac. Orthop., 104(1):67-72, 1993.
Rogers, T. L. Determining the sex of human remains through cranial morphology. J. Forensic Sci., 50:493-500, 2005.

Rosas, A.; Bastir, M.; Martinez-Maza, C. \& Bermudez de Castro, J. M. Sexual dimorphism in the Atapuerca-SH hominids: the evidence from the mandibles. J. Hum. Evol., 42:451-74, 2002.

Schleyer, F.; Ihm, P. \& Bensch, W. Sexual dimorphism of the outlines of the osseous orbit. Z. Rechtsmed., 69:168$72,1971$.

Schmittbuhl, M.; Le Minor, J. M.; Taroni, F. \& Mangin, P. Sexual dimorphism of the human mandible: demonstration by elliptical Fourier analysis. Int. J. Legal Med., 115:100-1, 2001.

Steyn, M. \& Iscan, M. Y. Sexual dimorphism in the crania and mandibles of South African whites. Forensic Sci. Int., 98:9-16, 1998.

Ursi, W. J.; Trotman, C. A.; McNamara, J. A. Jr. \& Behrents, R. G. Sexual dimorphism in normal craniofacial growth. Angle Orthod., 63:47-56, 1993.

Wescott, D. J. \& Moore-Jansen, P. H. Metric variation in the human occipital bone: forensic anthropological applications. J. Forensic Sci., 46:1159-63, 2001.

White, T. D. \& Folkens, P. A. Human osteology. $2^{\text {nd }}$ ed. San Diego, Academic Press, 2000.

Correspondence to:

Prof. Dr. Iván Suazo Galdames

Departamento de Anatomia Normal

Universidad de Talca

Avenida Lircay s/n oficina $\mathrm{N}^{\circ} 104$

Fono 56-71-201576

Chile

Email: isuazo@utalca.cl

Received : 22-08-2008

Accepted : 16-10-2008 
